\title{
MODEL TRANSFORMASI SAMPAH CANGKANG KERANG DI PERMUKIMAN KAWASAN PESISIR WATUKARUNG, PACITAN: Studi Etnoarkeologi ${ }^{1}$
}

\section{TRANSFORMATION MODEL OF MOLLUSK SHELLS DEBRIS FOUND IN COASTAL SETTLEMENT OF WATUKARANG AREA, PACITAN: An Etnoarchaeological Study}

\author{
Irsyad Martias \\ Mahasiswa Pascasarjana Antropologi Universitas Gadjah Mada, Yogyakarta \\ irsyadmrts@gmail.com
}

\begin{abstract}
Ecofact is a key for investigating mode of adaptation. Ecofact that commonly found on archaeological sites especially on inhabited caves were shell deposits. Fundamentally, the formation of archaeological record was resulted from behavioral processes and transformational processes. However, the problem is that we can't observe them, because those aspects had occurred in past time. Etnoarchaeological study can be used to solve those problems. Ethnoarchaeology studies have given contribution to interpret various aspects of human life of the past, starting from issues related to the technological and tools systems, subsistence, social systems, and processes of transformation. Therefore, this ethnoarchaeological research investigates behavioral system of coastal community who has collected, consumed, and discarded sea shells. The result of this research can be used as a model from formation processes of sea shell ecofact.
\end{abstract}

Key words: Ethnoarchaeology, Shell Gatherer, Transformational Model

\begin{abstract}
ABSTRAK
Ekofak merupakan kunci untuk mengungkapkan mode adaptasi manusia. Jenis ekofak yang kerap ditemukan pada situs-situs arkeologi terutama pada gua-gua hunian adalah sampah cangkang kerang. Pada hakikatnya, data arkeologi terbentuk dari serangkaian sistem tingkah laku dan akumulasi proses alih (transformational processes). Namun, kendalanya adalah aspek tingkah laku luput dari pengamatan arkeolog karena proses ini terjadi pada masa lampau. Studi etnoarkeologi adalah salah satu alat yang dapat diaplikasikan untuk memecahkan permasalahan tersebut. Penelitan etnoarkeologi bermanfaat untuk menafsirkan berbagai aspek kehidupan manusia masa lampau, mulai dari permasalahan yang berkaitan dengan sistem teknologi dan pemakaian alat, subsistensi, sistem sosial, hingga pengkajian tentang transformasi sampah dari aktivitas manusia pendukungnya, baik dalam dimensi konteks sistem maupun konteks arkeologi. Oleh sebab itu, penelitian etnoarkeologi ini mengkaji sistem tingkah laku masyarakat lingkungan Pantai Watukarung yang secara rutin mengumpulkan, mengonsumsi, dan membuang limbah kerang laut. Hasil dari penelitian ini dapat digunakan sebagai model mengenai pembentukan data ekofaktual sampah cangkang kerang laut.
\end{abstract}

Kata kunci: Etnoarkeologi, Pengumpul Kerang, Model Transformasi.

\footnotetext{
${ }^{1}$ Tulisan ini merupakan ringkasan skripsi penulis yang berjudul Model Transformasi Sampah Cangkang Kerang di Permukiman Kawasan Pesisir Watukarung, Pacitan: Studi Etnoarkeologi (2009). Tidak lupa penulis mengucapkan terima kasih kepada Drs. J. Susetyo Edy Yuwono yang telah membimbing penulis dalam menyelesaian tugas akhir tersebut.
} 


\section{PENDAHULUAN}

Etnoarkeologi adalah salah satu pendekatan dalam arkeologi yang berusaha menggunakan dan mengkaji data etnografi untuk menangani masalah-masalah arkeologi (Moendardjito, 1981: 1). Penelitan etnoarkeologi bermanfaat untuk menafsirkan berbagai aspek kehidupan manusia masa lampau, mulai dari permasalahan yang berkaitan dengan sistem teknologi dan pemakaian alat, subsistensi, sistem sosial, hingga pengkajian tentang transformasi sampah dari aktivitas manusia pendukungnya, baik dalam dimensi konteks sistem maupun konteks arkeologi (Mahirta, 1994: 155; David dan Kramer, 2001: 2).

Terkait dengan tujuan yang terakhir dan berdasarkan hasil laporan penelitian arkeologis dalam kerangka budaya prasejarah, ditemukan sampah cangkang kerang laut dengan jumlah berlimpah, terutama pada kelompok situs yang masih terpengaruh oleh lingkungan pesisir. Bukti-bukti tersebut antara lain ditemukan di pesisir pantai timur Sumatra Utara. Ekofak tersebut dikenal dengan istilah Kjokkenmoddinger (Ceci, 1984: 66).

Eksploitasi terhadap kerang laut pada Masa Prasejarah juga berlangsung di Pulau Jawa, terutama oleh komunitas manusia penghuni kawasan Pegunungan Selatan Jawa Barat dan kawasan karst Gunungsewu. Berdasarkan hasil laporan penelitian arkeologis di beberapa wilayah pantai selatan Jawa Barat, ditemukan sejumlah data cangkang kerang yang terkandung di dalam gua-gua hunian Prasejarah. Salah satu contohnya di situs Gua Keraton, Tasikmalaya. Dari gua tersebut diperoleh sampel ekofak cangkang kerang yang kemudian diidentifikasi taksonominya, di antaranya terdapat kerang laut dari Kelas Gastropoda dan Bivalvia (Mulyana, 2003: 1-2).

Penelitian yang lebih intensif telah dilakukan di kawasan karst Gunungsewu. Salah satu di antaranya adalah di situs Song Keplek, Pacitan. Di situs ini ditemukan berbagai macam jenis data cangkang kerang laut yang telah diidentifikasi taksonominya hingga tingkat famili. Ekofak cangkang kerang di atas, terdiri dari kelas Gastropoda dengan famili Buccinidae, Cypraeidae, Haliotedae, Muricidae, Neritidae, Patellidae, Policinis, Potamididae, Trochidae, Turbinidae, Volutidae, dan Elobiidae. Adapun kelas Pelecypoda/Bivalvia meliputi famili Arcidae, Cardiidae, Cymatiidae, Donacidae, Mytilidae, Pinnidae, Tellinidae, Veneridae, Anomiidae, Ostraeidae, dan Pectinidae (Simanjuntak, dkk., 2004: 141-144).

Menurut Hodder (1986: 13), faunal ecofact yang terdeposit di situs permukiman dapat dipastikan berasal dari sisa anatomi fauna yang tidak dapat dimakan atau dicerna oleh manusia. Pada umumnya ekofak tersebut terbentuk setelah mengalami proses diburu/dikumpulkan, dimasak, dimakan, dibuang, dan pada akhirnya menjadi sampah dapur.

Terdepositnya sampah cangkang kerang laut merupakan hasil dari proses tingkah laku manusia. Sebagai implikasinya proses tersebut membentuk suatu data arkeologi. Selain dipengaruhi oleh sistem tingkah laku, terbentuknya data arkeologi juga dipengaruhi oleh proses alih atau proses transformasi (Tanudirjo, 1987: 20). Namun, karena perbedaan ruang dan waktu, serangkaian kedua faktor di atas luput dari pengamatan arkeolog. Kenyataanya, objek arkeologi yang ditemukan hanya berupa sisa-sisa aktivitas manusia masa lampau. Studi etnoarkeologi adalah alat yang dapat diaplikasikan untuk memecahkan permasalahan tersebut, karena ia dapat menyumbangkan penafsiran terhadap keterkaitan antara data arkeologi sebagai budaya materi dengan perilaku manusianya (Tanudirjo, 1987:2).

Salah satu contoh wilayah yang dapat dijadikan studi kasus untuk mengetahui proses pembentukan dan transfomasi data ekofak sampah kerang laut, adalah wilayah permukiman Pantai Watukarung, Desa Watukarung, Kecamatan Pringkuku, Kabupaten Pacitan. Lingkungan wilayah Karst Pantai Watukarung membentuk suatu ciri subsistensi masyarakat pesisir yang menggantungkan kebutuhan hidupnya terhadap sumber daya marin. Selain aktivitas penangkapan ikan di perairan lepas yang dilakoni oleh komunitas nelayan, masyarakat Pantai Watukarung juga memanfaatkan ketersediaan sumber daya 
marin lainnya, yaitu aktivitas penangkapan dan pengumpulan kerang laut di wilayah pantai. Menurut penuturan pengumpul kerang laut, aktivitas tersebut dilakukan ketika air laut mengalami kondisi surut, sehingga berbagai macam kerang laut mudah ditemukan. Hasil dari penangkapan dan pengumpulan kerang laut tersebut dimanfaatkan sebagai bahan konsumsi rumah tangga sehari-hari. Adapun jenis kerang yang biasanya mereka kumpulkan adalah; Conidae, Muricidae, Neritidae, Tonnidae, Turbinidae, Trochidae, Arcidae, Mytillidae, Tellinidae, Veneridae, Cypraeidae.

Pola subsistensi masyarakat di permukiman Pantai Watukarung dalam upaya mengambil, mengonsumsi, dan membuang limbah makanan, akhirnya menghasilkan pembentukan data ekofak yang spesifik. Data yang dimaksud terutama berupa sampah cangkang kerang laut yang dapat dianalisis secara tafonomis.

Berangkat dari sistem tingkah laku masyarakat yang secara rutin mengumpulkan, mengonsumsi, dan membuang limbah kerang laut di lingkungan permukiman Pantai Watukarung, maka perlu dilakukan kajian etnoarkeologi untuk mengetahui aspek-aspek pembentukan dan transformasi data secara lengkap. Hal tersebut diharapkan mampU menjadi model yang berguna untuk menjawab atau membandingkan kasus-kasus arkeologi serupa. Menurut Clarke (1972: 1), model adalah alat yang menghubungkan observasi dengan ide teoritis atau hipotesis. Model adalah satuan hipotesis yang menyimpulkan hasil observasi yang menyajikan suatu kerangka kerja yang terprediksi dan akurat. Dengan kata lain, model merupakan alat abstraksi yang menghubungkan teori dan data empiris.

\section{AKTIVITAS PENGUMPULAN KERANG LAUT}

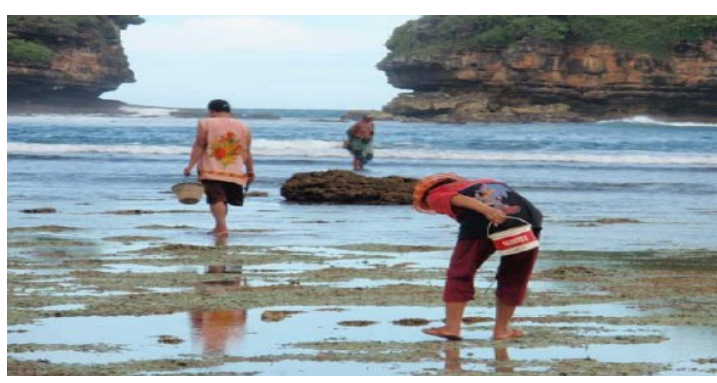

Foto 1. Mencari Kerang

Aktivitas pengumpulan kerang di Pantai Watukarang dilakukan oleh kaum perempuan maupun laki-laki dewasa. Kadangkala anak laki-laki dan perempuan yang masih berusia 8 - 10 tahun ikut terlibat dalam kegiatan ini. Meskipun tujuan utama mereka mengumpulkan kerang laut, namun hasil sampingan juga mereka peroleh, berupa teripang, rumput laut, dan terumbu karang. Kerang laut merupakan populasi yang melimpah jumlahnya dan sekaligus menjadi sumber makanan penting pada waktu-waktu tertentu, terutama pada musim paceklik ikan (lihat foto.1).

Lokasi pencarian kerang oleh masyarakat pesisir Watukarung berada di wilayah pantai bergisik pasir putih yang paling dekat dengan tempat mereka bermukim (lihat peta. 1). Pada kenyataannya gugusan pelataran karang di Pantai Watukarung dengan gisik berupa pasir putih memberikan efek positif terhadap kehidupan kerang laut. Karang berperan dalam meredam gempuran ombak, tempat bertahan pada saat air surut, mengatur kestabilan salinitas, meminimalisir penetrasi sinar matahari, dan menjaga kestabilan suhu air. Selain itu, karang merupakan media tumbuhnya rumput laut dan algae yang berperan dalam menyediakan nutrien sebagai sumber makanan bagi kerang laut jenis herbivora (Nyabakken, 1992: 250; Kuswanto, 2007: 105).

Masyarakat yang masih memilki tradisi mengumpulkan makanan langsung dari alam, pada umumnya menggunakan peralatan dan teknik yang sederhana (Netting,1977: 8). Hal tersebut tergambar pula pada komunitas pengumpul kerang laut di wilayah permukiman Pantai Watukarung. Untuk menangkap dan mengumpulkan kerang laut para pencari kerang menggunakan perangkat tertentu seperti; joro, cangkingan, dan kepas. Joro ialah tangkai besi yang salah satu ujungnya diruncingkan. Joro berfungsi untuk mencongkel kerang laut yang menempel atau yang bersarang pada batuan karang.

Berdasarkan ragam ukurannya, terdapat dua bentuk joro yang digunakan para pencari dan pengumpul kerang laut di Pantai Watukarung. Di antaranya adalah, joro 
berukuran pendek $( \pm 30 \mathrm{~cm})$ dan joro berukuran panjang $( \pm 100 \mathrm{~cm})$ (lihat foto. 2). Alat yang difungsikan sebagai wadah penampung kerang laut dapat dibedakan menjadi dua jenis, yaitu cangkingan dan kepas. Cangkingan adalah wadah yang terbuat dari sejumlah tali yang disimpul. Sesuai dengan namanya pemakaian cangkingan cukup dengan dijinjing.

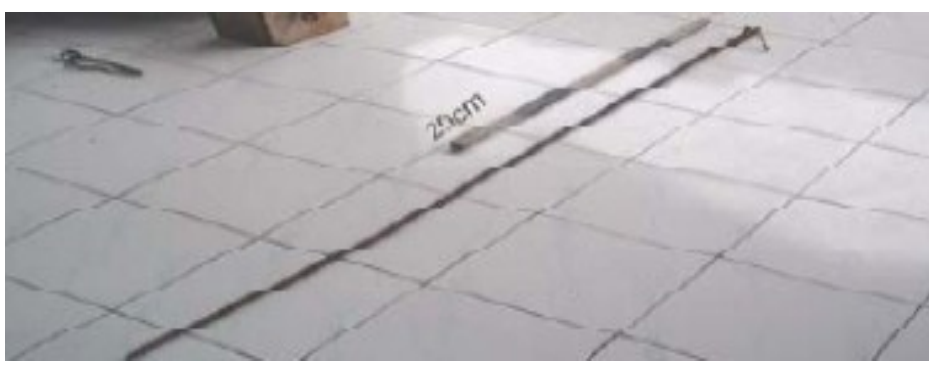

Foto 2. Joro

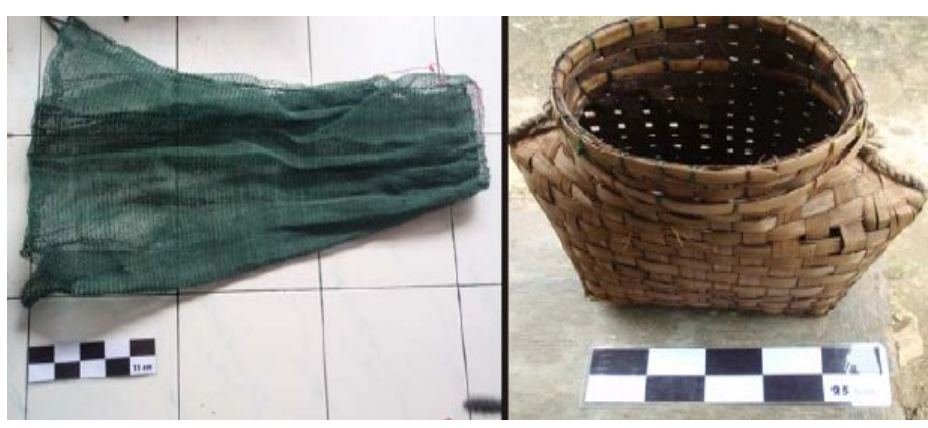

Kepas adalah keranjang yang terbuat dari anyaman bambu. Kepas dilengkapi pula dengan seutas tali yang berfungsi sebagai alat pengikat ke bagian pinggang penggunanya (pencari kerang) (lihat foto. 3). Sebagian pencari kerang laut juga menggunakan ember sebagai wadah penampung.

Aktivitas penangkapan kerang laut dilakukan ketika air laut surut. Masyarakat setempat menyebutnya dengan istilah pasatan. Kegiatan ini umumnya dilakukan dua kali sehari, yaitu ketika pagi hari sekitar pukul 08:00 WIB dan sore hari sekitar pukul 17:00 WIB, dengan persiapan dan peralatan yang sama. Lokasi pencarian kerang laut umumnya mengikuti relief pantai yang tersusun atas batuan karang. Beberapa jenis kerang laut menjadikan batuan karang tersebut sebagai tempat persembunyian, sehingga biota ini juga disebut dengan istilah karang-karangan.

Lamanya waktu pengumpulan kerang laut tergantung pada jumlah yang ingin mereka kumpulkan. Sebagai gambaran, untuk konsumsi enam orang anggota keluarga, mereka mengumpulkan 4-5 kg kerang. Mereka tidak akan mengumpulkan lebih banyak lagi karena sifat kerang laut mudah membusuk apabila tidak segera dimasak dan tidak segera dimakan. Setelah dikonsumsi, sampah cangkang kerang laut dibuang di lokasi yang berbeda-beda baik di atas permukaan maupun di bawah tanah. Dalam konteks permukiman, kelompok sampah cangkang kerang laut tersebar di pekarangan rumah dan di pesisir pantai. Masing-masing kelompok sampah tersebut mempunyai keberagaman jenis, konsentrasi, dan jumlah yang berbeda-beda pula.

Berdasarkan survei lapangan di lingkungan permukiman Pantai Watukarung, penulis menemukan sembilan titik konsentrasi sampah cangkang kerang laut yang tersebar di berbagai tempat (lihat peta. 2). Dapat diamati pada umumnya deposit sampah cangkang kerang laut yang berkonsentrasi tinggi sebagian besar terletak di pekarangan

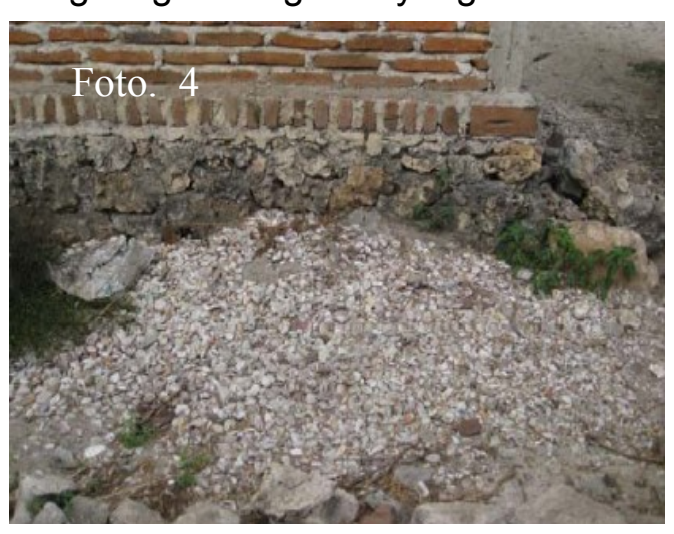
rumah warga. Pada umumnya deposit sampah cangkang tersebut terletak di dekat pintu dapur (lihat foto. 4).

Dapat disimpulkan bahwa timbunan deposit sampah cangkang kerang laut di atas, merupakan sisa hasil konsumsi rumah tangga yang secara rutin dibuang (KR01, KR02, KR03, KR04, KR05, KR07, KR09 ). Proses terbentuknya sampah cangkang kerang laut yang terdeposit di permukaan tanah diperkirakan dapat memakan waktu \pm 3 minggu. Setelah deposit sampah cangkang kerang laut 
menumpuk, para pemilik rumah akan menimbunnya di dalam tanah. Penimbunan deposit sampah cangkang kerang laut dilakukan karena pertimbangan kebersihan. Di samping itu, tumpukan sampah cangkang kerang laut yang "menggunung" dapat mengganggu ruang gerak keluar-masuk pintu dapur. Pada umumnya, penimbunan deposit sampah cangkang kerang laut tersebut disertai dengan sampah-sampah rumah tangga lain .

Secara kontekstual deposit sampah cangkang kerang laut di lingkungan permukiman Pantai Watukarung berdasarkan keletakannya dapat dibedakan menjadi dua yaitu; (1) sampah cangkang laut yang terdeposit di permukaan tanah, (2) sampah cangkang kerang laut yang terdeposit di dalam tanah. Konteks kedua adalah deposit sampah kerang laut yang diperoleh dari hasil temuan ekskavasi terhadap lubang sampah di lingkungan permukiman Pantai Watukarung (TP1 dan TP2) (lihat peta 2). TP 1 adalah lubang sampah sementara yang ditemukan pada salah satu warga Pantai Watukarung, sedangkan TP2 adalah Tempat Pembuangan Akhir (TPA) komunal masyarakat Pantai Watukarung. TP2 terletak dekat dengan area penambangan pasir (lihat tabel TP1,TP2 \& gambar stratigrafi TP1, TP2).

Tabel 1. Stratigrafi TP1

\begin{tabular}{|c|c|c|c|c|}
\hline STRATIGRAFI & SPIT & KATEGORI & JENIS & JUMLAH \\
\hline \multirow{2}{*}{$\begin{array}{l}\text { Lapisan 1: warna Hue } 7,5 \text { YR } 4 / 3 \text { (brown), ukuran low medium sand }(0,350 \text { - } \\
0,250 \mathrm{~mm} \text { ), kelembaban sedang, kekompakan sedang, tanah pasir geluhan } \\
(\text { loamy sand), permaebilitas baik, ketebalan } 3-5 \mathrm{~cm} \text {. }\end{array}$} & \multirow{6}{*}{1} & \multirow[t]{2}{*}{ Organik } & Terumbu karang & 6 \\
\hline & & & Koral & 4 \\
\hline \multirow{6}{*}{$\begin{array}{l}\text { Lapisan 2: warna Hue } 5 \text { YR } 7 / 6 \text { (orange), ukuran upper fine sand }(0,250- \\
0,177 \mathrm{~mm} \text { ), kelembaban sedang, kekompakan kecil, tanah pasir (sand), } \\
\text { permaebilitas baik, ketebalan } 3-8 \mathrm{~cm} \text {. }\end{array}$} & & \multirow{4}{*}{ Anorganik } & Fr. Kaca & 1 \\
\hline & & & Fr. Batrai & 1 \\
\hline & & & Fr. Gabus & 1 \\
\hline & & & Tali sandal & 1 \\
\hline & \multirow{5}{*}{2} & \multirow[b]{3}{*}{ Organik } & Cangkang kerang & 88 \\
\hline & & & Siput darat & 1 \\
\hline $\begin{array}{l}\text { Lapisan 3: warna Hue } 5 \text { YR } 3 / 6 \text { (dark reddish brown), ukuran low medium } \\
\text { sand }(0,350-0,250 \mathrm{~mm} \text { ), kelembaban sedang, kekompakan sedang, tanah } \\
\text { pasir geluhan (loamy sand), permaebilitas baik, ketebalan } 12-5 \mathrm{~cm} \text {. }\end{array}$ & & & Terumbu karang & 5 \\
\hline $\begin{array}{l}\text { Lapisan 4: warna Hue } 5 \text { YR } 3 / 2 \text { (dark reddish brown), ukuran upper fine } \\
\text { sand }(0,250-0,177 \mathrm{~mm}) \text {. kelembaban sedang, kekompakan sedang, tanah } \\
\text { pasir geluhan (loamy sand), permaebilitas baik, ketebalan } 5-15 \mathrm{~cm} \text {. }\end{array}$ & & Anorganik & Fr gerabah & 2 \\
\hline \multicolumn{3}{|l|}{ JUMLAH TOTAL } & & 1218 \\
\hline
\end{tabular}

Tabel 2. Stratigrafi TP2

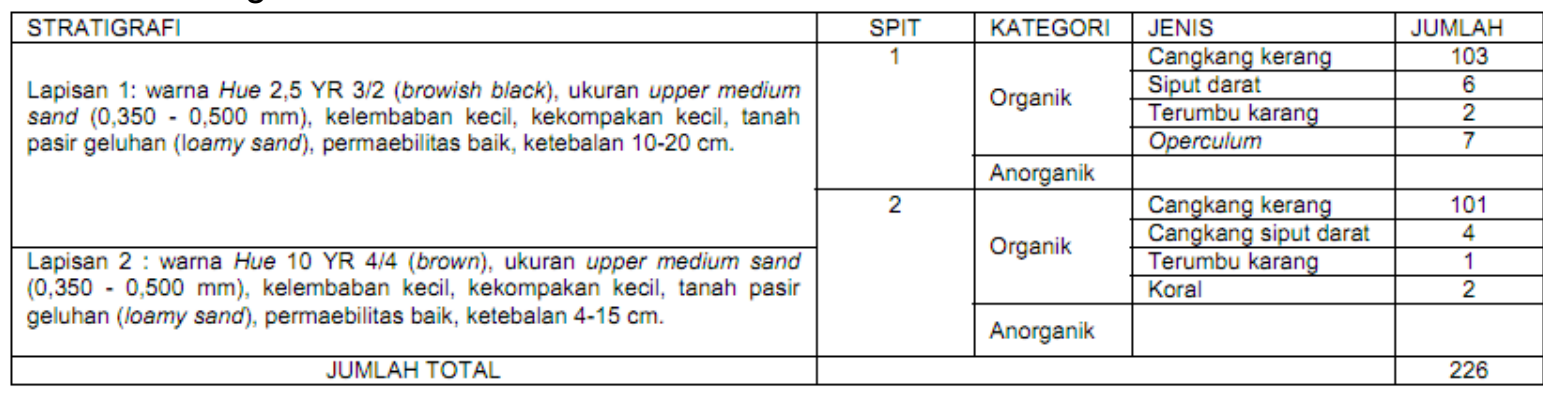


TP1

Dinding Barat

Dinding Utara
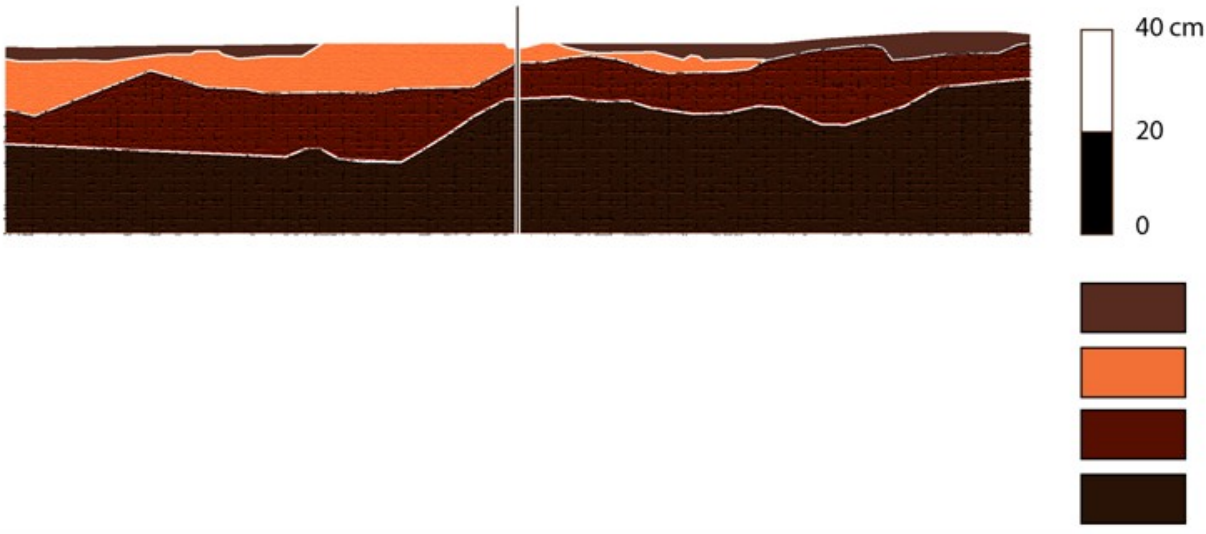

Lapisan 1

Lapisan 2

Lapisan 3

Lapisan 4

\section{TP2}

Dinding Barat

Dinding Utara

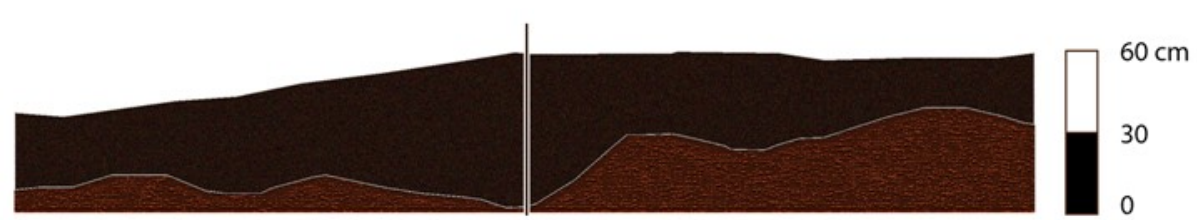

Lapisan 1

Lapisan 2 


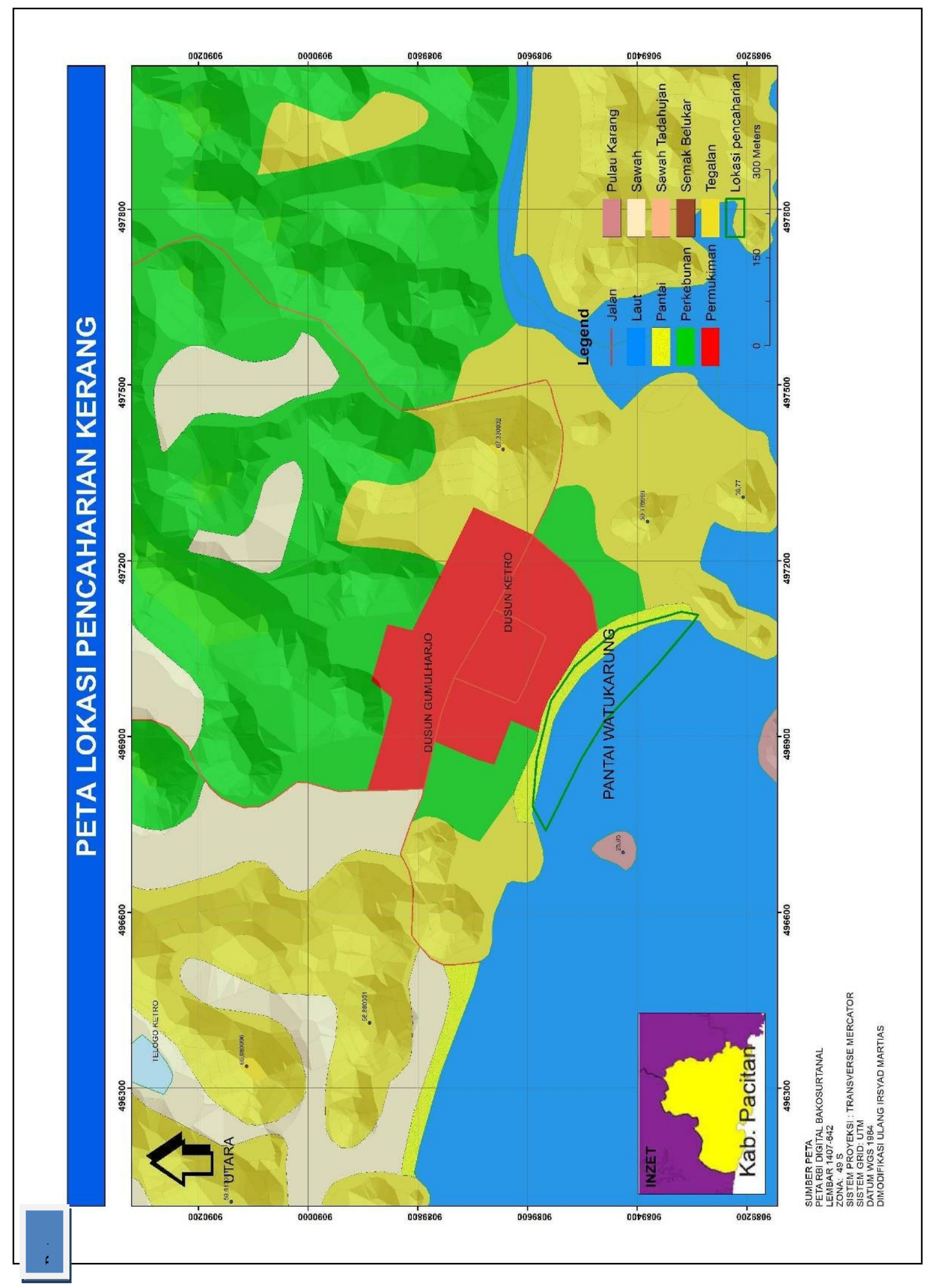




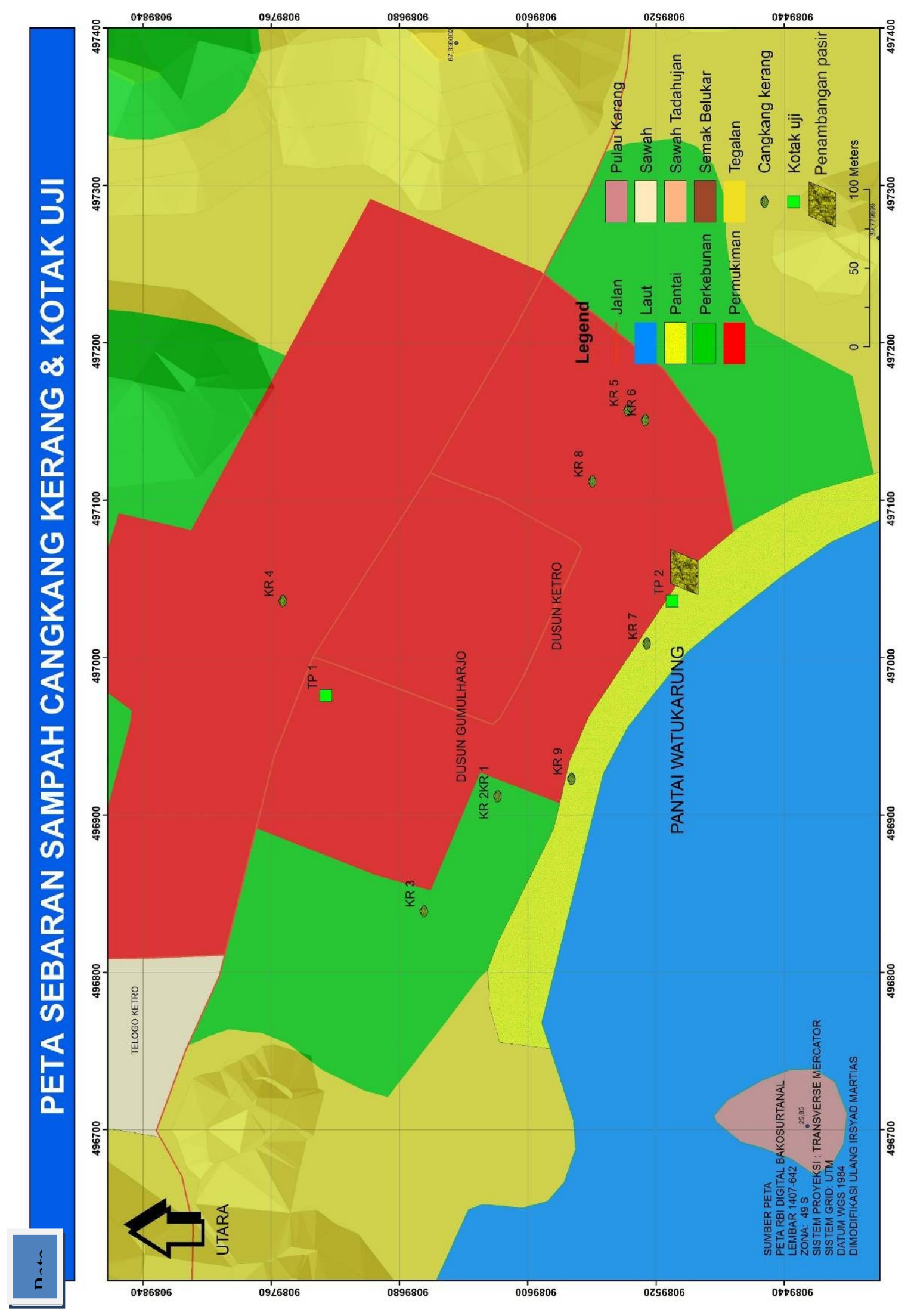




\section{MODEL TRANSFORMASI DATA SAMPAH CANGKANG KERANG LAUT DI LINGKUNGAN PERMUKIMAN PANTAI WATUKARUNG}

\section{Konsep Transformasi Data Arkeologi}

Menurut Schiffer (1987: 3-4) kedudukan benda arkeologi dapat dibagi menjadi dua, yaitu konteks sistem (systemic context) dan konteks arkeologi (archaeological contetxt). Konteks sistem mengacu kepada himpunan benda yang masih dipakai dalam suatu tingkah laku masyarakat yang masih hidup, sedangkan konteks arkeologi mengacu kepada sekumpulan benda yang tidak digunakan dalam suatu sistem tingkah laku masyarakatnya. Himpunan benda yang ditemukan di dalam konteks arkeologi inilah yang dikaji oleh arkeolog untuk merekonstruksi aspek behavioral manusia pada masa lampu.

Keseluruhan objek yang terdapat dalam konteks arkeologi merupakan hasil hubungan timbal balik antara tingkah laku manusia dan materi dengan tingkah laku budaya dan non budaya yang kemudian membentuk konteks data arkeologi. Konteks data diartikan sebagai karateristik data arkeologi yang dihasilkan melalui gabungan dua macam proses yaitu proses tingkah laku para pendukungnya (behavioral process) dan proses transformasi (transformation process) (Yuwono, 2003: 4).

Menurut Schiffer (1976: 25; 1987: 47), terdapat dua bentuk transformasi data arkeologi yaitu, cultural transformation dan non cultural transformation. Dapat diperinci cultural transfromation meliputi; daur menyamping (lateral cycling), daur ulang (recycling), reklamasi (reclamation), dan deposisi budaya (cultural deposition). Deposisi budaya adalah pergesaran data arkeologi dari dimensi konteks sistem menuju konteks arkeologis seperti halnya pembuangan (discard), penguburan (disposal of the dead), dan hilang (loss). Sementara itu, non cultural transformation adalah campur tangan persitiwa alam seperti erosi, pelapukan, hingga kerusakan-kerusakan yang disebabkan oleh binatang maupun tumbuh-tumbuhan.

Kendati demikian, tidak seluruh objek arkeologi di dalam konteks sistem akan terdeposisi ke dalam konteks arkeologi, dan tidak semua objek arkeologi yang masuk ke dalam konteks arkeologi dapat ditemukan kembali oleh arkeolog (Collins, 1972: 29). Kejadian ini Colins sebut sebagai bias (1972: 29). Collins (1972: 29) mengajukan tujuh sumber bias yang berpotensi terjadi di dalam proses pembentukkan data arkeologi. (1) Tidak semua pola tingkah laku menghasilkan budaya materi. (2) Manakala terbentuk, tidak dapat dipastikan pula seluruhnya akan bermuara ke konteks arkeologi. (3) Kalaupun objek tersebut terdeposit, tidak seluruhnya di dalam bingkaian konteks arkeologi yang jelas. (4) Tidak semua objek arkeologi yang berada di dalam konteks arkeologi selalu terawetkan. (5) Tidak semua objek arkeologi yang terawetkan berpeluang untuk terselamatkan. (6) Tidak semua objek arkeologi yang terselamatkan ditemukan oleh arkeolog. (7) Tidak semua benda yang ditemukan oleh arkeolog mampu diidentifikasi dengan baik.

Terkait dengan penjelasan di atas, Daniels (1972), berpendapat bahwa dalam rangkaian penelitian arkeologi, bias dapat disebabkan oleh tiga faktor, yaitu; (1) Historical factors dipengaruhi sejumlah aspek yang disebabkan cara si pembuat/pemakai objek arkeologi. (2) Post despositional factors disebabkan agen yang merubah kedudukan objek arkeologi setelah ia ditinggalkan si pemakai, hingga ditemukan kembali dan diteliti oleh arkeolog. (3) Resarch factors adalah faktor-faktor yang ditenggarai oleh pribadi peneliti, mulai dari penelitian lapangan hingga penerbitan naskah (Daniels, 1979: 202; Yuwono, 2003: 3).

Oleh sebab itu, perlu untuk dimengeri bahwa sejumlah proses transformasi termasuk di dalamnya bias harus didentifikasi sebelum penarikan kesimpulan mengenai human behavior serta budaya masa lalu diungkapkan. Oleh karena, ragam artikulasi cultural transfromation dan non cultural transformation serta bias sangat menentukan secara spesifik jenis konteks data ketika ditemukan oleh arkeologi (Yuwono, 1993: 5).

Konteks merupakan realita dari proses transformasi data. Konteks temuan dapat dibedakan menjadi dua jenis yaitu konteks primer dan konteks sekunder. Konteks primer 
merupakan kondisi di mana provenience (kedudukan dimensional data secara vertikal maupun horisontal), asosiasi (hubungan keruangan antara data), dan matriks (media yang melingkupi benda arkeologis) belum pernah terganggu sejak objek arkeologis terdeposisi hingga ditemukan kembali oleh arkeolog. Sementara itu, konteks sekunder adalah kondisi provenience, asosiasi, dan matriks sudah mengalami perubahan baik secara keseluruhan maupun sebagian (Sharer dan Ashmore, 2003: 135-137).

Lebih lanjut Sharer dan Ashmore (2003: 136-137) mengklasifikasi konteks primer menjadi dua tipe, yaitu konteks primer yang terkait dengan penggunaan budaya materi (use related primary context) dan konteks primer yang terpindahkan (transposed primary context). Sementara itu, konteks sekunder adalah hasil wujud dari perubahan konteks primer, entah oleh perilaku manusia sesudahnya untuk kepentingan tertentu (use-related secondary context) maupun oleh proses campur tangan alam (natural secondary context).

Berdasarkan kerangka pembagian konteks di atas, dan dari hasil analisis kontekstual, dapat disimpulkan sementara bahwa jenis konteks deposit sampah cangkang kerang laut di lingkungan permukiman Pantai Watukarung adalah sebagai berikut (lihat gambar 4.1):

1. Use related primary context

Konteks ini dihasilkan melalui deposisi di tempat objek material dibuat dan digunakan oleh para pendukungnya. Objek material yang dimaksud dalam hal ini adalah sampah cangkang kerang laut yang terdeposit di pekarangan rumah hunian.

2. Transposed primary context

Konteks ini dihasilkan melalui tingkah laku yang tidak berhubungan dengan pembuatan dan atau penggunaan suatu objek materi namun berhubungan dengan pembuangan dan penimbunan deposit tertentu. Peristiwa ini adalah gejala tercampurnya sampah-sampah rumah tangga atau benda-beda lain dengan sampah cangkang kerang laut pada lokasi deposit. Dalam hal ini, Transposed primary context direpresentasikan oleh lubang sampah yang terletak di perkarangan rumah (kotak TP1).

3. Use-related secondary context

Adalah aktivitas pengadukan yang dilakukan manusia sesudahnya, baik sengaja maupun tidak sengaja. Dalam Hal ini use-related secondary context direpresentasikan dengan teraduknya sampah cangkang kerang laut yang terdeposit di Tempat Pembuangan Akhir (kotak TP2) akibat terjadinya aktivitas penambangan pasir untuk kepentingan jual beli.

4. Natural secondary context

Hal yang berpengaruh adalah agen-agen non budaya seperti gangguan oleh peristiwa-peristiwa alam tertentu. Analisis ini dititikberatkan pada gejalagejala alam yang berpengaruh di lingkungan pantai, antara lain abrasi, erosi, dan akibat pelapukan serta perilaku binatang. Penulis tidak menemui jenis konteks ini dalam TP 1 maupun TP 2.

Berdasarkan kerangka konteks di atas, dapat disimpulkan bahwa proses transformasi yang bekerja pada data sampah cangkang kerang laut di permukiman Pantai Watukarung adalah jenis konteks use related primary context, transposed primary context, dan use-related secondary context. Dalam penelitian ini use related primary context diwakili oleh temuan permukaan. Sementara itu, transposed primary context diwakili kotak TP1, sedangkan kotak TP2 mewakili gambaran use-related secondary context. 


\section{Indikasi Transformasi Budaya (Cultural Transformation) dalam Pembentukan Konteks Primer}

Sebagai langkah awal untuk menjelaskan uraian di atas, penulis mengacu kepada diagram "flow model" milik Schiffer (1976), yang tertuang di dalam bukunya yang berjudul Behavioral Arcahaeology. Schiffer (1976: 47), menyusun skema teoritis tentang proses transformasi calon data arkeologis dan bagaimana pula data tersebut beroperasi pada konteks sistem (S) menuju dimensi konteks arkeologi (A) (lihat bagan 1).

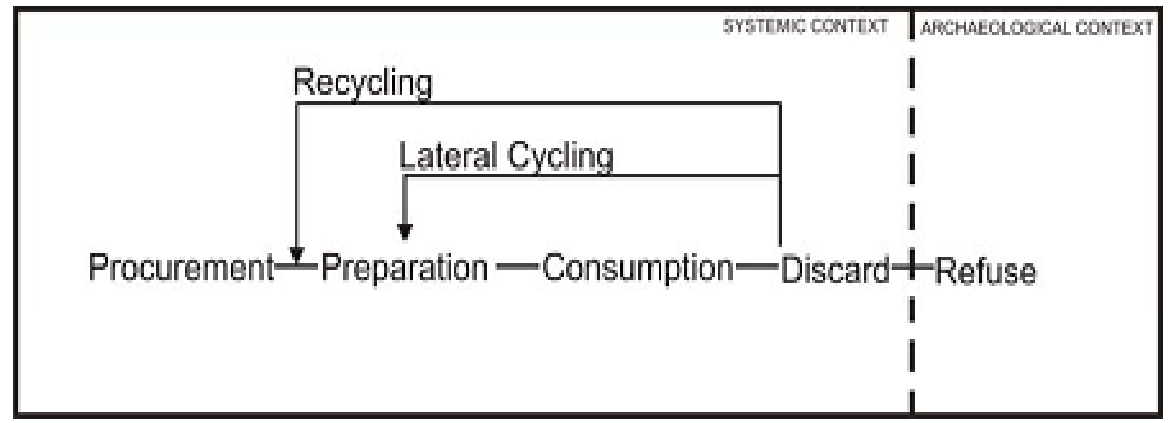

Bagan 1.

Perolehan (procurement) adalah tahap yang dilakukan manusia dalam memperoleh suatu hasil alam yang akan digunakan atau dikonsumsi. Bahan-bahan hasil perolehan tersebut perlu dipersiapkan terlebih dahulu dengan melakukan proses pengolahan (preparation).

Setelah tahapan di atas, proses selanjutnya adalah tahap penggunaan atau pengonsumsian (consumption). Kadangkala sisa dari bahan yang telah dikonsumsi dapat digunakan kembali untuk keperluan tertentu. Proses tersebut dikenal dengan daur menyamping (lateral cycling) dan daur ulang (recycling). Daur menyamping (lateral cycling) adalah pemanfaatan dari sisa bahan yang telah dibuang (discard) tanpa proses persiapan (preparation). Sementara itu, daur ulang (recycling) adalah pemanfaatan kembali barang yang telah dibuang (discard) melalui proses persiapan (preparation).

Secara garis besar skema teoritis di atas, dapat menjawab proses transformasi yang dialami oleh sampah cangkang kerang laut yang berada di wilayah permukiman Pantai Watukarung. Perolehan (procurement) adalah proses ketika kerang laut tersebut diambil oleh komunitas pengumpul kerang dari pesisir pantai dengan menggunakan joro, kepas atau cangkingan.

Persiapan (preparation) adalah proses pembersihan dan proses pemasakan kerang laut menjadi bahan makanan. Peralatan yang digunakan dalam proses pembersihan antara lain ember dan bakulan. Sementara itu, alat yang digunakan dalam proses pemasakan antara lain alat pembakaran dan wajan. Proses pemasakan juga bertujuan untuk mengeluarkan daging dari cangkangnya. Selain itu, pengeluaran daging dari cangkang kerang juga dapat dilakukan secara mekanis dengan cara memecahkan cangkang kerang dengan menggunakan benda-benda keras.

Pembuangan (discard) (S1) dapat dilihat dari sampah cangkang kerang laut berupa sisa hasil konsumsi yang terdeposit di pekarangan rumah. Kondisi temuan permukaan dapat menggambarkan transformasi budaya yang dialami cangkang kerang laut setelah keluar dari konteks sistem namun belum sepenuhnya masuk ke konteks arkeologi.

Sampah cangkang kerang laut tidak hanya berakhir pada tahap pembuangan (discard). Sebagian dari deposit sampah cangkang kerang laut tersebut adapula yang terkena proses daur ulang (recycling) (S2). Hal tersebut ditandai dengan pengambilan cangkang kerang Mytillidae untuk diolah menjadi suplemen bahan makanan ternak unggas. Dipilihnya cangkang kerang Mytillidae disebabkan cangkang kerang tersebut lebih tipis dan lebih lunak dibandingkan jenis cangkang kerang yang lain serta dianggap mengandung unsur karbohidrat yang tinggi. 

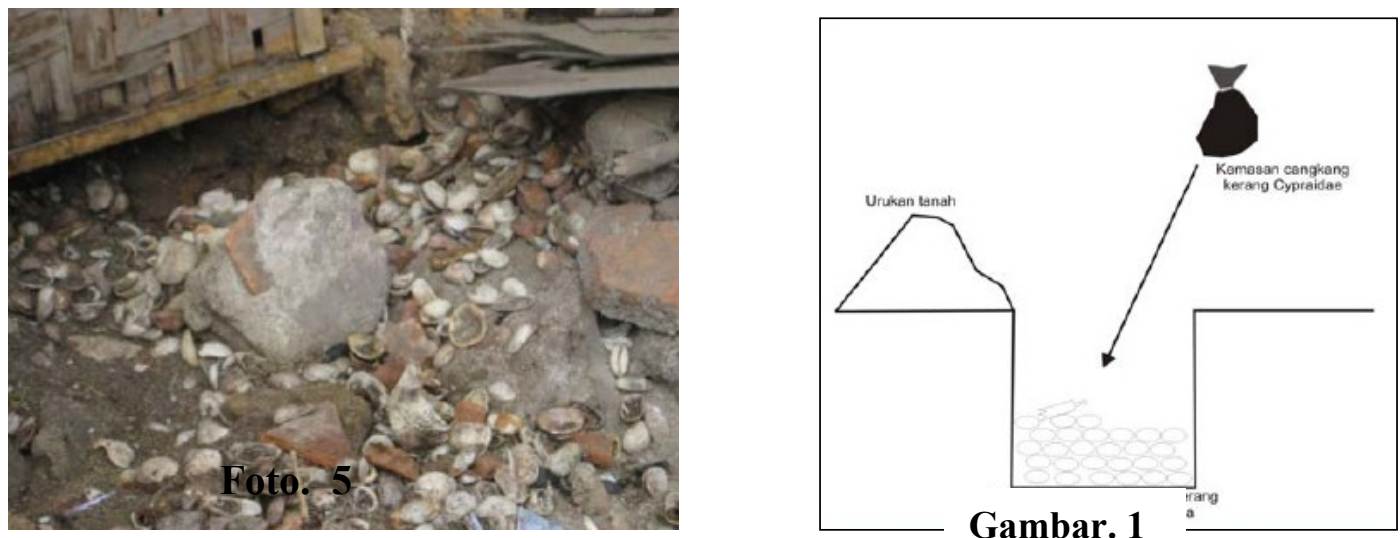

Proses pembuangan (discard) (S1) pada umumnya dilakukan berulang kali. Tentunya tindakan tersebut berakibat "menggunungnya" sampah cangkang kerang laut yang berada di pekarangan rumah komunitas pencari kerang. Seperti yang telah dijelaskan di atas, deposit sampah cangkang kerang laut yang telah "menggunung" biasanya dikubur (disposal of the dead) (S3) di lubang sampah karena alasan kebersihan. Pada umumya lokasi lubang sampah terletak di pekarangan rumah bagian belakang.

Persitiwa yang patut diperhatikan adalah tidak seluruh deposit sampah cangkang kerang laut tersebut terkubur seluruhnya, adapula sebagian kecil sampah cangkang kerang laut yang tetap terletak di permukaan tanah. Kemungkinan hal tersebut diakibatkan kelalaian pencari kerang ketika melakukan proses penguburan (disposal of the dead) (S3). Kelompok sampah cangkang ini merupakan bagian yang berpeluang besar memasuki dimensi use related primary context (A1)

Kendati demikian, deposit sampah cangkang kerang laut yang telah dikubur dapat dibongkar kembali apabila pencari kerang memperoleh kerang Cypraeidae dengan jumlah yang besar. Selanjutnya kerang Cypraeidae juga ikut dikubur bersama-sama dengan kelompok sampah cangkang kerang laut maupun sampah rumah tangga lainnya yang terlebih dahulu terdesposisi. Sebelum dikubur, cangkang kerang Cypraeidae dikemas dengan kantong plastik. Tindakan seperti ini dapat dikategorikan sebagai proses

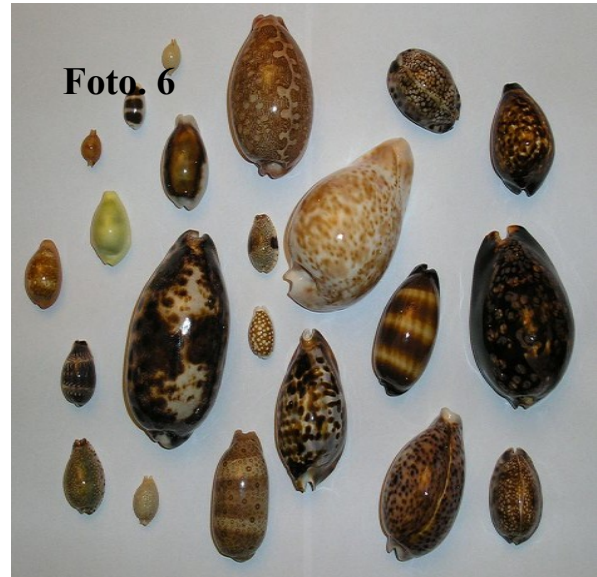
perawatan (maintenance) (S4) terhadap cangkang kerang Cypraeidae (lihat gambar 1). Meskipun cangkang kerang Cypraeidae tidak mempunyai fungsi teknis namun cangkang kerang ini mempunyai nilai ekonomis. Cangkang kerang ini dapat dijual kepada pengrajin kerang yang berminat untuk dibuat perhiasan karena bentuknya yang bagus (lihat foto 6). Terdapat dua peristiwa penting yang sering mengubah kedudukan kelompok deposit cangkang kerang laut. Pertama, adalah proses perawatan (maintenance) (S5) lubang sampah. Kedua, adalah proses daur menyamping (lateral cycling) (S6) yang dilakukan pencari kerang.

Alasan dilakukannya proses perawatan www.seashell.com (maintenance) (S5) di atas, antara lain disebabkan daya tampung lubang sampah tidak mencukupi kapasitasnya.

Peristiwa tersebut disebabkan oleh penambahan jumlah sampah akibat proses penguburan (disposal of the dead) (S3) terhadap cangkang kerang laut dan sampah rumah tangga yang baru (lihat gambar 2). Akibat proses perawatan di atas (maintenance) (S5), kelompok sampah cangkang kerang laut dan sampah rumah tangga lainnya yang terlebih dahulu berada di dalam lubang sampah harus dibuang (discard) (S6) di Tempat Pembuangan Akhir komunal (TPA) (kecuali kelompok cangkang kerang Cypraeidae). Tempat Pembuangan Akhir (TPA) tersebut berada di tepi Pantai Watukarung. 
Proses daur menyamping (lateral cycling) (S7) dilakukan terhadap kelompok cangkang kerang laut Cypraeidae. Alasan dilakukan proses ini adalah adanya permintaan cangkang kerang Cypraeidae dari pengrajin kerang (lihat gambar. 3). Sementara itu, kelompok sampah cangkang laut yang tetap terdeposit di lubang sampah (kotak TP2) merupakan kelompok sampah cangkang kerang laut yang berpeluang besar memasuki dimensi konteks arkeologi transposed primary context (A2).

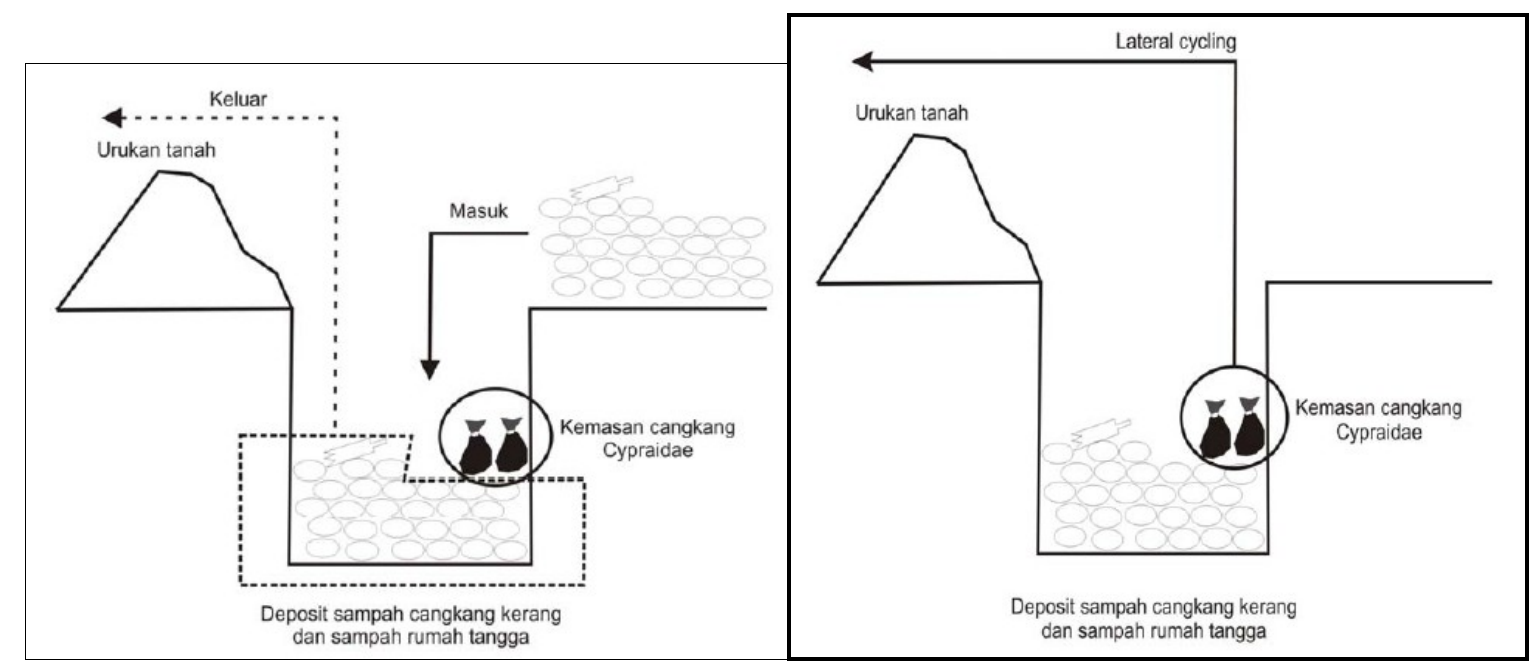

\section{Indikasi Transformasi Budaya (Cultural Transformation) dalam Pembentukan Konteks Sekunder}

Penjelasan ini dilakukan terhadap kotak TP2 yang merupakan tempat deposit sampah cangkang kerang laut di Tempat Pembuangan Akhir Komunal (TPA). Pada dasarnya sampah cangkang kerang laut yang terdeposit di sini merupakan sekumpulan sampah cangkang kerang laut yang dibuang (discard) (S7) dari pekarangan rumah. Dalam hal ini sampah cangkang kerang tersebut tidak lagi mengambil bagian dari sistem tingkah laku komunitas pencari kerang.

Jika kita melihat stratigrafi terhadap kotak TP2, terlihat lapisan paling atas (lapisan 1) bukan merupakan lapisan pasir pantai (sand) yang pada umumnya berwarna kuning (orange), lapisan 1 tersusun oleh tanah pasir geluhan (loamy sand) berwarna coklat kehitam-kehitaman(brownish black). Setelah itu, lapisan 2 disusun oleh tanah pasir geluhan (loamysand) berwarna coklat (brown) (lihat gambar stratigrafi TP2 hal 8).

Secara teoritis proses geomorfik yang terjadi kontiniu di lingkungan pantai adalah perpindahan material pasir (sand) karena aktifitas angin. Proses tersebut dikenal dengan istilah deflasi pasir (Sunarto, 1991: 5). Oleh karena itu, idealnya lapisan tanah di lingkungan pantai secara vertikal diawali oleh susunan tanah pasir (sand) yang berwarna terang dan dilanjutkan di bawahnya secara bertahap oleh lapisan tanah pasir geluhan (loamy sand) dan atau humus yang kecenderungannya berwarna lebih gelap (Gerard, 1992: 137).

Kondisi stratigrafi TP2 menunjukkan adanya proses penambangan tanah pasir yang bertujuan untuk kepentingan jual beli. Perisitiwa penambangan tanah pasirlah yang mengakibatkan rusak bahkan hilangya (loss) sebagian sampah cangkang kerang yang terdeposit di kotak TP2. Proses ini merupakan cerminan terbentuknya use-related secondary context (A3).

Menurut Schiffer, terdapat empat dimensi yang harus diperhatikan dalam proses transformasi data (dalam Yuwono, 1993: 33). Keempat dimensi transformasi ini meliputi; (1) Dimesi formal (formal dimension) yang berhubungan dengan dimensi fisik suatu data arkeologi. (2) Dimensi spasial (spatial dimension) yang berhubungan dengan lokasi atau 
kedudukan sebuah data arkeologi pada saat ditemukan. (3) Dimensi kuantitatif (frequency dimension) yang berhubungandengan peristiwa pengurangan atau penambahan jumlah tipe-tipe data arkeologi tertentu. (4) Dimensi relasional (relational dimension) yang menyangkut pola hubungan, baik berupa asosiasi maupun korelasi

Berdasarkan pembagian di atas, dapat disimpulkan adanya bias yang mempengaruhi perubahan kualitas dan kuantitas deposit sampah cangkang kerang laut, baik pada konteks primer maupun sekunder. Bias yang dimaksud terjadi pada ranah historical factor (konteks sistem) dan post deposition factor (konteks arkeologi). Secara keseluruhan, proses transformasi sampah cangkang kerang laut di lingkungan permukiman Pantai Watukarung adalah sebagai berikut (lihat bagan. 2).

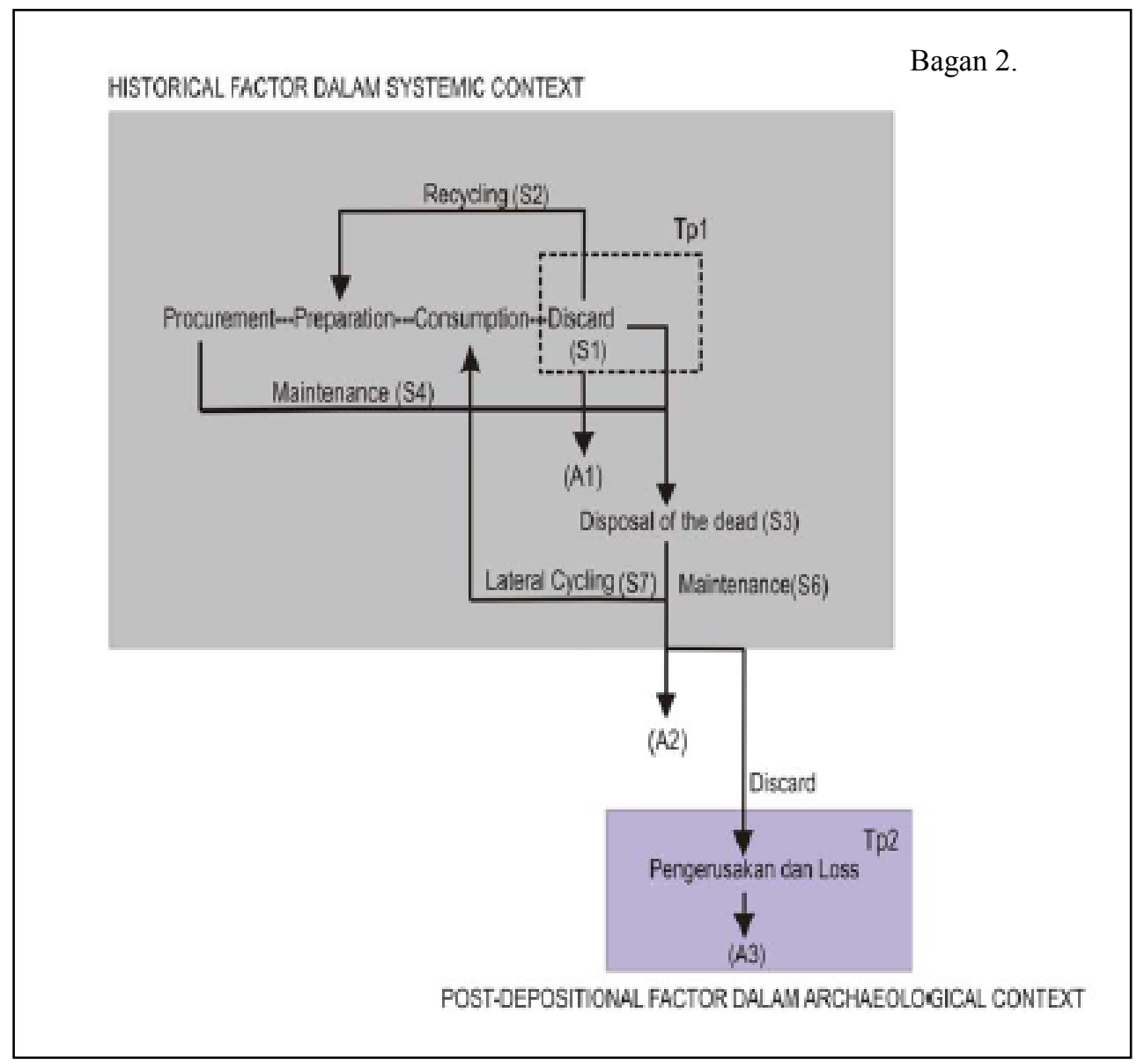

Dimensi keruangan (spasial dimension) ditandai dengan terjadinya perubahan tempat deposit sampah cangkang kerang laut di lingkungan Permukiman Pantai Watukarung, dimulai dari sampah yang terkosentrasi di permukaan, ekskavasi kotak TP1, hingga berakhir ke TP2. Berdasarkan keletakannya, discard (A1/A2) merupakan discard primary refuse yaitu discard yang berdekatan dengan lokasi pembuatan, sedangkan (A3) merupakan discard secondary refuse yaitu discard yang berjauhan dengan lokasi pembuatan (Rathje dan Shiffer, 1982: 116). Hal tersebut karena (A3) merupakan sisa hasil sampah cangkang kerang laut yang tidak kembali pada konteks sistem (systemic context) yang pada akhirnya dipindahkan ke tempat pembuangan akhir komunal (final deposit).

Dimensi kuantitatif (frequency dimension) ditandai dengan pengurangan dan penambahan jumlah deposit sampah cangkang kerang laut. Adapun penyebabnya adalah rangkaian proses penguburan (S3), daur ulang (S2), daur menyamping (S7), perawatan, maupun hilang akibat proses penambangan tanah pasir. Dimensi formal (formal 
dimention) ditandai dengan ditemukannya individu cangkang kerang laut yang sebagian atau sepenuhnya pecah karena aktivitas pencangkulan pada saat proses perawatan lubang sampah (kotak TP1) (A2) dan penambangan tanah pasir pantai (sand) (kotak TP2) (A3). Dalam hal ini, tidak seluruh individu cangkang kerang tersebut pecah akibat proses pengolahan. Dimensi (relational dimension) ditandai dengan ditemukanya individu cangkang kerang non konsumsi akibat proses perawatan cangkang kerang Cypraeidae (maintenance) (S4) dan masuknya unsur non kerang di lubang sampah (TP1).

\section{PENUTUP}

Sesuai dengan tujuan penelitian ini, maka penjelasan mengenai proses transformasi di atas, merupakan suatu bentuk model mengenai transformasi data ekofaktual sampah cangkang kerang laut. Telah dijelaskan di awal, temuan sampah ekofak cangkang kerang laut di gua-gua hunian arkeologis menunjukkan frekuensi yang cukup tinggi. Namun, bukan berarti dengan frekuensi temuan yang tinggi tersebut tidak terjadi perubahan kualitas dan kuantitas konteks temuan.

Dalam perspektif transformasi, pada hakikatnya semua data arkeologi menjalani proses yang panjang mulai saat dibuat, dipakai, hingga pada momentum tertentu bendabenda tersebut tidak berperan lagi dalam sistem tingkah laku masyarakat masa lalu. Benda-benda yang sudah tidak digunakan dalam konteks sistem pada akhirnya akan dibuang. Pada tahap tertenu "sebagian" benda-benda ini ditemukan lagi oleh arkeolog dengan berbagai macam jenis konteks.

Dengan dibuatnya model transformasi data sampah cangkang kerang laut berdasarkan hasil studi etnoarkeologi yang menitikberatkan pada masalah tafonomi. Paling tidak, gambaran model tersebut dapat membantu melacak bagaimana proses transformasi yang terjadi pada konteks data ekofak sampah cangkang kerang laut pada situs-situs yang masih terpengaruh oleh lingkungan pantai.

Jika meninjau peran penalaran studi etnoarkeologi dapat dibedakan menjadi tiga bentuk yaitu (Tanudirjo, 1987: 38): (1) Sebagai interpretasi-eksplanasi, dalam hal ini data etnografi diterapkan sebagai materi penjelasan dan rekonstruksi pola tingkah laku yang menyebabkan terbentuknya data arkeologi. (2) Sebagai pembentuk atau penyaran hipotesis, maksudnya adalah, data etnografi memberikan kontribusi berupa hipotesis, yang pada gilirannya hipotesis ini harus diuji kembali pada data yang bebas, baik data etnografi yang lain maupun data arkeologi. (3) Sebagai penilai hipotesis, yang berarti, hasil penelitian etnoarkeologi dapat digunakan dalam menelaah ragam hipotesis yang dilahirkan dari interpretasi data arkeologi sehingga membenarkan atau menggugurkan hipotesis tersebut.

Dengan demikian, kedudukan penelitian ini adalah sebagai interpretasi-eksplanasi atas terbentuknya konteks data ekofak sampah cangkang kerang laut beserta transformasi yang dialaminya. Dengan kata lain, penelitian etnoarkeologi ini difokuskan pada studi tafonomi. Di sisi lain, penelitian ini juga sebagai pembentuk atau penyaran hipotesis. Dalam artian, model tersebut sebagai gambaran proses transformasi data sampah cangkang kerang laut. Hasil interpretasi yang diperoleh dari penelitian ini memang selayaknya harus diuji keabsahannya dengan data bebas, baik berupa data etnoarkeologi yang lain maupun data arkeologi. Hasil penelitian ini diharapkan dapat menjembatani kesenjangan antara kerangka teori yang digunakan dengan fakta-fakta atau data arkeologi yang ditemukan pada situs-situs yang mengandung deposit ekofak cangkang kerang laut.

Penelitian ini juga mempunyai beberapa kelemahan. Bagaimana pun, distorsi tetap terjadi sehingga menghasilkan sejumlah bias. Hal tersebut mengingat penulis melakukan penggeneralisasian terhadap aspek-aspek pola tingkah laku komunitas pencari kerang laut dalam perolehan, pengolahan, pengonsumsian, dan pembuangan. Selain itu, pengambilan sampel (melalui ekskavasi) deposit sampah cangkang laut kerang tidak proposional dengan jumlah rumah hunian. Dalam perspektif transformasi, bias jenis ini dikenal dengan istilah research factors. Rinciannya sebagai berikut: tidak semua pola 
tingkah laku pembuangan (discard) teramati, dan di antara sampah cangkang kerang laut yang terdeposit tidak semuanya dapat ditemukan dan diidentifikasi.

\section{KEPUSTAKAAN}

Ceci, Lynn. 1984." Shell Midden Deposits as Coastal Resources". Sumber: World Archaeology, Vol. 16, No. 1, Coastal Archaeology (Jun., 1984), hal. 62-74. Dipublikasi oleh Taylor \& Francis, Ltd.Stable URL: http://www.jstor.org/stable/124688. Diakses: 12/06/2009 09:40

Daniels, S.G.H. 1972. "Research Design Models" dalam Models in Archaeology, David L. Clarke (ed). London: Methuen and Co.

David, Nicholas dan Kramer, Carol. 2001. Ethnoarchaeology in Action. Cambridge: The Press Syndicate of Univeristy of Cambrdige.

Clarke, David L. 1972. "Models and Paradigism in Contemporary Archaeology" dalam Models in Archaeology, David L. Clarke (ed). London: Metheun and Co.

Collins, Michael B. 1979. "Sources of Bias in Processual Data: An Appraisal" dalam Sampling in Archaeology, Muller James (ed). Arizona: The University of Arizona Press.

Gerard, John. 1992. Soil Geomorphology: An Intergration of Pedology and Geomorphology. London: Chapman \& Hall Publisher.

Hodder, lan. 1986. Reading the Past: Current Approaches to Interpretation in Archaeology. Melbourne: Press Syndicate of The University of Cambridge.

Kuswanto, Gregorius Dwi. 2007."Eksploitasi Sumberdaya Akuatik Oleh Komunitas Penghuni Song Jrebeng, Gunungkidul: Kajian Lingkungan dan Ekofak Organik". Skripsi. Yogyakarta: Jurusan Arkeologi, Fakultas IImu Budaya, UGM.

Mahirta. 1994. "The Use Etnographic Data for Interpreting Prehistoric Exchanges" dalam Jejak-Jejak Budaya, (ed) Sumijati Atmosudiro, Anggraeni, Tular Sudarmadi. Yogyakarta: Asosiasi Prehistori Indonesia Rayon II. HIm 155-168.

Moendardjito. 1981. "Etnoarkeologi: Perananya Dalam Pengembangan Arkeologi di Indonesia" dalam Majalah Arkeologi No 1. Jakarta: Fakultas Sastra UI.HIm 17-29.

Mulyana, Dadan. 2003. Analisis Fauna Situs Gua Keraton, Kecamatan Karangnunggal Kabupaten Tasikmalaya Propinsi Jawa Barat dalam "Nuansa Arkeologi 1". Banten: IAAI Komisariat Jawa-Banten. HIm 1-11.

Netting, Robert. 1977. Cultural Ecology. Philippines: Cummings Publishing Company, Inc.

Nyabakken, James W. 1992. Biologi Laut: Suatu Pendekatan Ekologis. Jakarta: PT Gramedia.

Rathje, William L. dan Michael B Schiffer. 1982. Archaeology. New York: Harcourt Brace Jovanovich. 
Schiffer, Michael B. 1976. Behavioral Archaeology. New York: Harcourt Brace Jovanovich.

1987. Formation Processes of The Archaeological Record. Alburquerque: University of New Mexico Press.

Sharer, Robert J. dan Wendy Ashmore. 2003. Archaeology, Discovering Our Past. California: Mayfield Publishing.

Simanjuntak, dkk. 2004. Prasejarah Gunungsewu. Jakarta: IAAI.

Sunarto. 1991. "Geomorfologi Pantai". Makalah dipresentasikan dalam Kursus Singkat Pengelolaan dan Perencanaan Pantai. 2-14 September 1991.

Tanudirjo, Daud Aris. 1987. "Laporan Penelitian Penerapan Etnoarkeologi di Indonesia". Laporan Penelitian. Yogyakarta: Jurusan Arkeologi, Fakultas Sastra, UGM.

Yuwono, Edy J.S. 1993." Transformasi Batuan Candi (Sebuah Kajian Tafonomi). Laporan Penelitian. Yogyakarta: Fakultas Sastra, UGM.

2003."Aspek-Aspek Teknis Ekskavasi Dalam Kerangka Pemahaman Transformasi Data". Disampaikan pada Bimbingan Pelatihan Metodologi Penelitian Arkeologi, Puslitarkenas, Yogyakarta, 2003. 
